\title{
New oxorhenium (V) complex with an imidazol [NN] /hydantoin [SN] mixed ligand system, and radiochemical behavior of its oxotechnetium (V) complex analog
}

\author{
Noura Saad Al-Hokbany ${ }^{1 *}$, Refaat Mhafouz ${ }^{1}$, Ibrahim Jammaz AlJammaz ${ }^{2}$ \\ ${ }^{1}$ King Saud University, Department of Chemistry, College of Science, Riyadh, Kingdom of Saudi Arabia; \\ *Corresponding Author: nhokbany@ksu.edu.sa \\ ${ }^{2}$ Cyclotron and Radiopharmaceuticals Department, King Faisal Specialist Hospital and Research Center, Riyadh, Kingdom of Saudi \\ Arabia.
}

Received 8 January 2011; revised 4 February 2011; accepted 20 February 2011.

\section{ABSTRACT}

A $\left[\mathrm{ReO}(\operatorname{Imz})(\mathrm{Hyd})\left(\mathrm{H}_{2} \mathrm{O}\right)_{2} \mathrm{OH}\right]$ complex was successfully synthesized by the ligand exchange method using oxorhenuim citrate and an imidazole /Hydanton mixed ligand system. Geometry optimization of complex has been carried out using DFT at the B3LYP/LANL2DZ functional in singlet state. B3LYP predicated infrared spectrum of the geometrically optimized structure using the same level of the theory and the same base set showed good agreement with experimentally observed values. The spin allowed singlet-singlet electronic transition of the [ReO(Imz)(Hyd) $\left.\left(\mathrm{H}_{2} \mathrm{O}\right)_{2} \mathrm{OH}\right]$ complex was calculated with time dependent density function theory (TD-DFT) and the UV-Vis spectra has been discussed on this basis. The complex was characterized using microanalysis and IR, UVVis, NMR and mass spectroscopic. The technetium tracer $\left[{ }^{99 \mathrm{~m}} \mathrm{TcO}(\mathrm{Imz})(\mathrm{Hyd})\left(\mathrm{H}_{2} \mathrm{O}\right)_{2} \mathrm{OH}\right]$ has also been synthesized by two methods using ${ }^{99 \mathrm{~m}} \mathrm{Tc}$-gluconate as a precursor or; by direct reduction. The radiochemical purity of the complex was over $95 \%$ as measured by thin layer chromatography. In vitro studies showed that the complex possessed good stability under physiological conditions. The partition coefficient indicated that the complex hydrophilic and the electrophoresis results showed that the complex cationic. Biodistrbution in mice showed that the complex accumulated in heart uptake of $9.53 \pm 3.87 \% \mathrm{ID} / \mathrm{gm}$ at $5 \mathrm{~min}$ and good retention $(6.37 \pm 1.21) \% \mathrm{ID} / \mathrm{gm}$ at $60 \mathrm{~min}$. One hour after the injection, the heart/liver, heart/lung and heart/blood radioactivity ratios were $0.46,1.04$ and 0.56 , respectively. These findings indicate that the complex might be suitable for myocardial imaging.

Keywords: Imidazole (Imz); Hydantoin (Hyd); mixed ligand; $[\mathrm{ReO}]^{3+}$; DFT; ${ }^{99 \mathrm{~m}} \mathrm{Tc}$-gluconate

\section{INTRODUCTION}

Many metallic elements play a crucial role in living systems. As a result of their tendency to easily lose electrons to form positively charged ions, metals readily interact with electron rich biological molecules such as proteins and DNA, or bind with small molecules that are vital to life, such as oxygen. Because metals are so extensively used in biological systems, it was reasonable to investigate the potential use of metal ions alone and incorporated into drugs as well as the use of coordination complexes for medicinal purposes [1]. The use of metals offers many opportunities for the design of radiopharmaceuticals through the modification of environment around the metal that allow specific in vivo targeting to be incorporated into the molecule. The coordination chemistry of the metal will determine the ultimate geometry and stability of the radiopharmaceutical [1].

Radiopharmaceuticals, i.e., chemicals or cellular structures that include a radionuclide, are routinely used in nuclear medicine, for both diagnostic and treatment purposes. Currently, ${ }^{99 \mathrm{~m}} \mathrm{Tc}$ is the most commonly employed radionuclide to SPECT (single photon emission computed tomography), because of its ideal nuclear properties $\left(\mathrm{t}^{1} / 2=6 \mathrm{hr}, \gamma\right.$-particle energy $\left.140 \mathrm{keV}\right)$, availability and low cost [2]. The coordination chemistry of rhenium and technetium is currently attracting much attention due to the radionuclide-based application in radiopharmaceuticals. Rhenium belongs to the same group of the periodic table (VII) as technetium and exhibits similar chemical properties. Rhenium is often used as a non-radioactive alternative to technetium for struc- 
tural characterization $[3,4]$.

The mixed ligands concept and particularly the SN/N combination have been applied for the preparation of neutral oxorhenium and oxotechnetium complexes. Chemically, the synthesis of $\mathrm{Re}(\mathrm{V})$ complexes requires the presence of metal-containing chemical cores that are, stable enough to exist in aqueous solutions and versatile enough to combine with the selected ligands. An example of such a core is the oxo form $\left[\mathrm{Re}^{\mathrm{V}} \mathrm{O}\right]^{3+}$, in which the +5 oxidation state of the metal is stabilized by the oxo-core $[5,6]$. The literature shows that a search for new radiopharmaceuticals requires studies of new oxorhenium (V) complexes with nitrogen and sulfur donor sets, as well as investigations of the chemical behavior of their ${ }^{99 \mathrm{~m}} \mathrm{Tc}$ analogs. In this work, we report the synthesis and characterization of a novel complex of rhenium of the general type $[\mathrm{ReO}(\mathrm{Imz})(\mathrm{Hyd}) \mathrm{OH}]$. We have also studied the radiochemical properties of the corresponding technetium complex, which was prepared by two methods.

Nowadays, $a b$ intio computational techniques are a potent tool for research. Chemistry has changed from a purely empirical science into a discipline in which deductive theory, as represented by first-principles calculations using computers, is increasingly important for interpretation and guidance of experimental work. Recent developments in this area include the field of density functional theory which meets with the requirements of being accurate. Currently density functional theory (DFT) is commonly used for geometric optimization and electronic structure of transition metal complexes. It meets the requirements of being accurate, easy to use and fast enough to allow the study of relatively large molecules of transition metal complexes [7,8]. Geometric optimization and electronic structure of $[\mathrm{ReO}(\mathrm{Imz})(\mathrm{Hyd}) \mathrm{OH}]$ has been determined on the basis of the density functional theory (DFT) calculations and additional information about binding has been obtained by NBO analysis. The accuracy of the DFT calculations can be tested by comprising the available experimental data against calculation values. In our case study the experimental data available will be the data gathered from spectroscopic measurements such as UV-Vis, FTIR and NMR data.

\section{COMPUTATIONAL DETAILS}

The GAUSSIAN 03program [9] (Gaussian 03 program) was used in the calculations. The complex was treated as open shell-system and no symmetry constrains were applied. Geometrical optimization of the investigated complex was carried out with Beck's three parameter exchange functional B3LYP using the Los Alamos LANL2DZ spilt-valence basis set [10,11]. A harmonic vibrational analysis was performed following the geometrical optimization of the complex at the same level of theory B3LYP and the same basis set [12]. An additional d function with exponent $a=0.3811$ and an $\mathrm{f}$ function with exponent $a=2.033$ on the rhenium atom were added [13]. Natural bond orbital (NBO) calculations were performed with the NBO code [14] included in GAUSSIAN 03. The optimized geometry for various forms of the MBT molecule is shown in Figure 1. The two tautomeric forms of MBT were subjected to geometry optimization at B3LYP/6-31G**.

\section{EXPERIMENTAL}

\subsection{Materials and Methods}

All the reagents used in the synthesis were commercially available and were used without further purification. The $\mathrm{ReO}$ (citrate) $)_{2}^{-}$precursor was prepared according to the literature [15]. IR was recorded on a Perkin Elmer spectrophotometer 1000 in the spectral range $200-4000 \mathrm{~cm}^{-1}$ with sample in the form of $\mathrm{KBr}$ pellets. Elemental analyses were performed on a Perkin-Elmer Analyzer 2400. ${ }^{1} \mathrm{H}-{ }^{13} \mathrm{C}$ NMR spectra were obtained in DMSO-D 6 on JEOL NMR $400 \mathrm{MHz}$. Electronic spectrum was measured on a UV-Vis Beckman Du-70 spectrophotometer in the range $190-700 \mathrm{~nm}$ in aqueous medium.

${ }^{99 \mathrm{~m}} \mathrm{TcO}_{4}^{-}$in saline solution was eluted from a ${ }^{99} \mathrm{Mo} /{ }^{99 \mathrm{~m}} \mathrm{Tc}$ generator obtained from $\mathrm{Cis}$ Bio International Elumatic III, B.p.32. (France). Chemical reactions were monitored by thin- layer chromatography on instant thin layer chromatography (ITLC, SG-TLC) using Whatman No.1 chromatography paper (Whatman International Ltd. UK) and Silica gel-60 $\mathrm{F}_{254}$ TLC-aluminium sheets (Alltech). HPLC separations were carried out using a normal phase silica column (Econosil $10 \mu \mathrm{m} \times 264$ $\mathrm{mm}$ ) using a dual pump (Jasco-pu-2089 plus Quaternary Gradient); methanol/ dichloromethane (1:1) was used as the mobile phase with a flow rate of $0.5 \mathrm{ml} / \mathrm{min}$. A JASCO chromatography system equipped with a variable wavelength ultraviolet monitor (JASCO, UV-2075 plus, intelligent UV/Vis detector) was set up in tandem with a Canberra flow through $\mathrm{NaI}$ radioactivity detector (TI). Ultraviolet absorption and radiochromatogram was monitored at $254 \mathrm{~nm}$. Chromatography was acquired and analyzed using BORWIN software.

Electrophoresis measurements were carried out in 0.1 $\mathrm{M}$ sodium borate buffer ( $\mathrm{pH} 8$ ) using Whatman No.1 chromatography paper. The paper was presoaked in the same buffer for 5 minutes before spotting the radiolabeled sample at the middle of the paper. After a potential of $160 \mathrm{~V}$ was applied for $120 \mathrm{~min}$, the chromatography paper was dried, and the distribution of radioactivity was measured in a $\gamma$-well counter. The radiochemical 
purity of the prepared complex was determined by spotting on ITLC-SG strips.

The biodistribution experiments for the ${ }^{99 \mathrm{~m}} \mathrm{Tc}$ complex were performed in normal female mice to ascertain. the in vivo distribution profile of the radiotracers according to literature [16]. The animal biodistribution experiments were performed in accordance with institutional, national and international regulations governing the safe and humane use of laboratory animals in research.

Mice (BALB/C, 25 - $30 \mathrm{~g}$ ) were injected via the tail vein with $0.1 \mathrm{ml}$ of the radiotracer formulated in saline. Each dose contained $20-30 \mu \mathrm{Ci}$ of radioactivity. Animals were sacrificed at 5, 30 and 60 min post injection and the organs of interest and blood were collected, weighed, and the radioactivity was measured with an automatic gamma counter (Cobra II). The percentage of the injected dose per gram was then calculated for all tissues using a stored sample of the injection solution to estimate the total dose injected per mouse.

\subsection{Synthesis of $\left[\mathrm{ReO}(\mathrm{Imz})(\mathrm{Hyd})\left(\mathrm{H}_{2} \mathrm{O}\right)_{2} \mathrm{OH}\right]$.}

$\mathrm{NaReO}_{4}$ (1 mmol, $0.273 \mathrm{~g}$ ) was added to a solution of $\mathrm{SnCl}_{2}(1 \mathrm{mmol}, 0.256 \mathrm{~g})$ in citric acid $(0.5 \mathrm{M}, 5 \mathrm{ml})$. Hyd ( $1 \mathrm{mmol}, 0.1008 \mathrm{~g}$ ) and Imz ( $2 \mathrm{mmol}, 0.136 \mathrm{~g})$ in ethanol were added dropwise to the mixture. The reaction mixture was stirred at room temperature for $3 \mathrm{hr}$. The $\mathrm{pH}$ was adjusted to 9 with $\mathrm{NaOH}(0.5 \mathrm{M})$, and the precipitate was recrystallized in hot Methanol and acetone according to literature [17]. Attempts to make a single crystal were unsuccessful and the complex was precipitated in micro crystalline form with $98 \%$ yield of the compound: Anal. Calc.(found) for $\mathrm{C}_{6} \mathrm{H}_{7} \mathrm{~N}_{4} \mathrm{O}_{4} \mathrm{Re}$ : $\mathrm{C}$, 18.7(18.9); H, 1.83(2.05); N, 14.5(14.56); Re, 48.3 (47.2)\%. IR (KBr, v/cm $\left.{ }^{-1}\right): 916(\mathrm{Re}=\mathrm{O}), 560(\mathrm{Re}-\mathrm{N})$, 430(Re-O). ${ }^{1} \mathrm{H}$ NMR (DMSO, ppm): 10(s, NH), 3.8 (s, $\left.\mathrm{CH}_{2}\right), 7-7.1(t, \mathrm{CH}=\mathrm{CH}), 7.73-7.77(t, \mathrm{CH}=\mathrm{N}) .{ }^{13} \mathrm{C}$ NMR (DMSO, ppm): 122(C=C), 135 $(\mathrm{C}=\mathrm{N}), 158.8(\mathrm{O}=\mathrm{C}$ - $\mathrm{NH}), 174,171(\mathrm{O}=\mathrm{C}-\mathrm{C}), 47.7\left(\mathrm{CH}_{2}\right)$. UV-Vis $\left(\mathrm{H}_{2} \mathrm{O}\right.$; $\lambda_{\max }[\mathrm{nm}]\left(\varepsilon ; \mathrm{dm}^{3} \mathrm{~mol}^{-1} \mathrm{~cm}^{-1}\right): 191(2026), 203(2058), \mathrm{sh}$ 245(288). MS (m/z): 385[M] .

\subsection{Synthesis of $\left[{ }^{99 m} \mathrm{TcO}(\mathrm{Imz})(\mathrm{Hyd})\left(\mathrm{H}_{2} \mathrm{O}\right)_{2} \mathrm{OH}\right]$}

\subsubsection{Direct Method}

The preparation of the ${ }^{99 \mathrm{~m}}$ Tc-complex was achieved by addition of sodium borohydride $(0.29 \mathrm{mmol}, 11.1 \mathrm{mg})$ in freshly prepared saline to a mixture containing ${ }^{99 \mathrm{~m}} \mathrm{TcO}_{4}^{-}(0.7 \mathrm{ml}, 27 \mathrm{mCi})$ and ligands (Imz: $9.0 \mathrm{mg}$, $0.13 \mathrm{mmol}$; Hyd: $10.4 \mathrm{mg}, 0.10 \mathrm{mmol}$ ) with stirring. The mixture was allowed to stand for $45 \mathrm{~min}$ for complete reaction and then extracted with dichloromethane $(3 \times 1.5 \mathrm{ml})$. The combined organic extracts were dried over $\mathrm{MgSO}_{4}$, which was filtered off. The radioactivity content of both the aqueous and organic phase is measured separately. The organic solvent was expelled under a mild stream of nitrogen, and ethanol was added so that a final solution $30 \%$ ethanol final solution was obtained for complex according to literature [16]. The radiolabeling yield was $88 \% \pm 3 \%$ with $96 \%$ radiochemical purity.

\subsubsection{Ligand Exchange Method}

Preparation of the ${ }^{99 \mathrm{~m}}$ Tc complex was accomplished using ${ }^{99 \mathrm{~m}}$ Tc-gluconate as the precursor [16]. A vial containing a lyophilized mixture of $200 \mathrm{mg}$ sodium gluconate and $0.2 \mathrm{mg}$ of $\mathrm{SnCl}_{2} \cdot 2 \mathrm{H}_{2} \mathrm{O}$ was reconstituted with 5 $\mathrm{ml}$ of water. A volume of $0.5 \mathrm{ml}$ of this solution was mixed with [ $\left.{ }^{99 \mathrm{~m}} \mathrm{Tc}\right] \mathrm{NaTcO}_{4} 1 \mathrm{mmol}\{(0.5-1 \mathrm{ml}$ with an activity of $5-50 \mathrm{mCi}(185-1850 \mathrm{MBq})\}$. The precursor ${ }^{99 \mathrm{~m}}$ Tc-gluconate, (radiochemical purity $>95 \%$ ) was added to a centrifuge tube containing the mixed ligands. The mixture was stirred in a vortex mixer and left to react at room temperature for $10 \mathrm{~min}$. The complex was extracted with dichloromethane $(3 \times 1.5 \mathrm{ml})$ and the organic layer was dried with $\mathrm{MgSO}_{4}$, filtered and analyzed by ITLC and HPLC.

\section{RESULTS AND DISCUSSION}

The reaction between oxorhenium citrate and the imdizole/hydantoin mixed ligands system lead to the formation of $\mathrm{a}\left[\mathrm{ReO}(\mathrm{Imz})(\mathrm{Hyd}) \mathrm{OH}\left(\mathrm{H}_{2} \mathrm{O}\right)_{2}\right]$ complex according to Scheme 1.

We found that the labeling yield of the final ${ }^{99 \mathrm{~m}} \mathrm{Tc}$ complex was higher when the direct reduction method was used compared with the ligand exchange method.

\subsection{Geometry Optimization, Charge Distribution, Electronic Structure and NBO Analysis}

The geometry of the $\left[\mathrm{ReO}(\mathrm{Imz})(\mathrm{Hyd}) \mathrm{OH}\left(\mathrm{H}_{2} \mathrm{O}\right)_{2}\right]$ complex was optimized in a singlet state by the DFT method with the B3LYP function as shown in Figure 1. The calculated bond lengths and angles for $\mathrm{Re}=\mathrm{O}, \mathrm{Re}-\mathrm{N}$ and $\mathrm{Re}-\mathrm{O}$ are in quite good agreement with the values reported for other oxorhenium complexes of related structure as listed in Table 1 [18].

Table 2 presents the atomic charges from the Natural Population Analysis (NPA) for $\left[\mathrm{ReO}(\mathrm{Imz})(\mathrm{Hyd}) \mathrm{OH}\left(\mathrm{H}_{2} \mathrm{O}\right)_{2}\right]$. The calculated charge on the rhenium atom is considerably lower than the formal charge of +5 . This difference is a result of significant charge donation from the oxo, $\mathrm{OH}$ and N-ligand donors. The charge on the oxo ligand is significantly smaller than $(-2)$ and less negative than the charge on the $\mathrm{OH}$ ligand, indicating that there is higher electron density delocalization from the oxo core to the rhenium [19]. 
Table 1. Some geometrically optimized bond length $\left(\mathrm{A}^{\circ}\right)$ and angles $\left({ }^{\circ}\right)$ for $[\mathrm{ReO}(\operatorname{Imz})(\mathrm{Hyd}) \mathrm{OH}$ $\left.\left(\mathrm{H}_{2} \mathrm{O}\right)_{2}\right]$.

\begin{tabular}{llll}
\hline Bond length $\left(\mathrm{A}^{\circ}\right)$ & & Bond angle $\left({ }^{\circ}\right)$ & B3LYP/LANL2DZ \\
\hline $\operatorname{Re}(17)-\mathrm{O}(18)$ & $1.7196(1.7071)$ & $\mathrm{O}(18)-\operatorname{Re}(17)-\mathrm{O}(19)$ & $107.9908(119.7782)$ \\
$\operatorname{Re}(17)-\mathrm{O}(18)$ & $1.9253(1.8662)$ & $\mathrm{N}(12)-\operatorname{Re}(17)-\mathrm{N}(10)$ & $90.2611(102.792)$ \\
$\operatorname{Re}(17)-\mathrm{N}(12)$ & $2.0531(1.9322)$ & $\mathrm{N}(12)-\operatorname{Re}(17)-\mathrm{O}(18)$ & $100.4543(100.260)$ \\
$\operatorname{Re}(17)-\mathrm{N}(10)$ & $2.0861(1.9737)$ & $\mathrm{N}(10)-\operatorname{Re}(17)-\mathrm{O}(19)$ & $93.4614(120.723)$ \\
$\operatorname{Re}(17)-\mathrm{O}(19)$ & $1.9253(1.862)$ & $\mathrm{N}(17)-\operatorname{Re}(11)-\mathrm{O}(12)$ & $102.2092(102.792)$ \\
$\operatorname{Re}(17)-\mathrm{O}(23)$ & $2.1676(1.9322)$ & $\mathrm{N}(12)-\operatorname{Re}(17)-\mathrm{O}(24)$ & $90.0916(102.792)$ \\
$\mathrm{N}(12)-\mathrm{C}(5)$ & $1.3998(1.398)$ & $\mathrm{O}(23)-\operatorname{Re}(17)-\mathrm{O}(24)$ & $99.2639(100.07)$ \\
$\mathrm{N}(10)-\mathrm{C}(2)$ & $1.4066(1.398)$ & $\mathrm{Re}(17)-\mathrm{O}(19)-\mathrm{H}(20)$ & $117.5155(116.99)$ \\
\hline
\end{tabular}

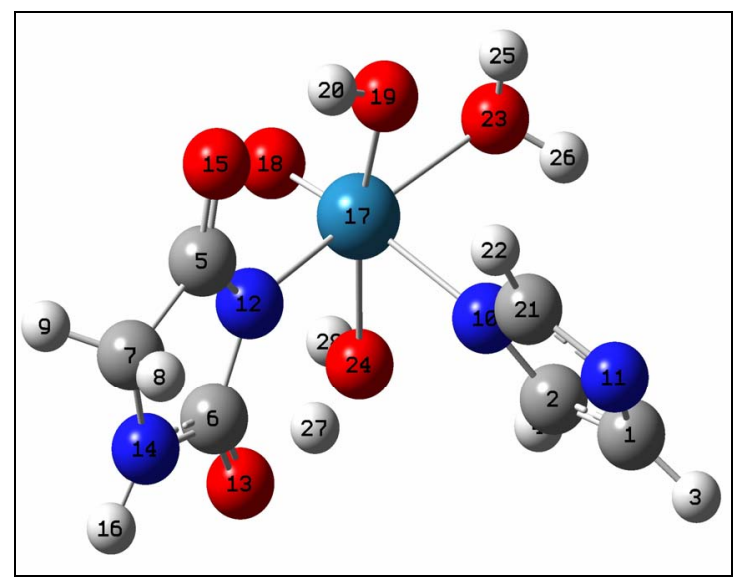

Figure 1. The molecular structure of $[\mathrm{ReO}(\mathrm{Imz})(\mathrm{Hyd})$ $\left.\mathrm{OH}\left(\mathrm{H}_{2} \mathrm{O}\right)_{2}\right]$.

Table 2. Atomic charges from the natural population anaylsis (NPA) for $\left[\mathrm{ReO}(\mathrm{Hyd})(\mathrm{Imz}) \mathrm{OH}\left(\mathrm{H}_{2} \mathrm{O}\right)_{2}\right]$.

\begin{tabular}{cc}
\hline Atom & Atomic charge \\
\hline $\mathrm{Re}(17)$ & 1.437 \\
$\mathrm{~N}(12)$ & -0.475 \\
$\mathrm{~N}(10)$ & -0.562 \\
$\mathrm{O}(18)$ & -0.413 \\
$\mathrm{O}(19)$ & -0.742 \\
$\mathrm{C}(5)$ & -0.126 \\
$\mathrm{C}(2)$ & 0.374 \\
\hline
\end{tabular}

Table 3. The occupancies and hybridization of the calculated $\mathrm{Re}-\mathrm{O}$ natural bond orbitals (NBOs) for $[\mathrm{ReO}(\mathrm{Hyd})(\mathrm{Imz})$ $\left.\mathrm{OH}\left(\mathrm{H}_{2} \mathrm{O}\right)_{2}\right]$.

\begin{tabular}{ccc}
\hline BD & Occupancy & Hybridization of NBO \\
\hline $\operatorname{Re}(17) \equiv \mathrm{O}(18)$ & $1.95735(0.2786)$ & $0.5196(\mathrm{sd})_{\mathrm{Re}}+0.8544(\mathrm{sp})_{\mathrm{O}}$ \\
& $1.78553(0.2268)$ & $0.3809(\mathrm{~d})_{\mathrm{Re}}+0.9246(\mathrm{p})_{\mathrm{O}}$ \\
& $1.78648(0.1699)$ & $0.4145(\mathrm{~d})_{\mathrm{Re}}+0.9101(\mathrm{p})_{\mathrm{O}}$ \\
$\operatorname{Re}(17)-\mathrm{O}(19)$ & $1.89301(0.1667)$ & $0.3359(\mathrm{sd})_{\mathrm{Re}}+0.9419(\mathrm{p})_{\mathrm{O}}$ \\
& $1.88269(0.1662)$ & $0.2906(\mathrm{~d})_{\mathrm{Re}}+0.9569(\mathrm{p})_{\mathrm{O}}$ \\
$\operatorname{Re}(17)-\mathrm{N}(12)$ & $1.89452(0.200)$ & $0.4653(\mathrm{~d})_{\mathrm{Re}}+0.8852(\mathrm{p})_{\mathrm{N}}$ \\
\hline
\end{tabular}

Table 3 presents the occupancy and hybridization of the calculated Re-O bond orbitals (NBOs) for the
$\left[\mathrm{ReO}(\mathrm{Imz})(\mathrm{Hyd}) \mathrm{OH}\left(\mathrm{H}_{2} \mathrm{O}\right)_{2}\right]$ complex. Three natural bond orbitals were detected for the core Re-O bond, andone bond orbital was observed for the $\mathrm{Re}-\mathrm{O}$ bond of the $\mathrm{OH}$ ligand. The Re-O bond orbital of $\sigma$-character is polarized toward the $\mathrm{O}$ atoms, and the $\mathrm{s}$ and $d$-orbitals of the $\mathrm{Re}$ participate in the bonding. The $\mathrm{Re}-\mathrm{O}$ bond orbitals of $\pi$ character are significantly polarized towards the metal atom and only the $d$-orbitals of Re are included into the bonding.

The complex adopts an octahedral structure in which two water molecule is weakly coordinated to the Re atom, as seen from the unusual bond length of 2.1676 $\mathrm{pm}$. It is worth mentioning that these calculations are performed in the gas phase. Dissolution of the investigated complex in aqueous medium could result in another $\mathrm{H}_{2} \mathrm{O}$ molecule being coordinated to the rhenium to form a distorted octahedral structure. These results were further confirmed by measuring UV-Vis spectra of the complex in different solvents; shifts in $\lambda_{\max }$ were recorded by changing the solvent, which indicates coordination of an additional solvent molecule with the Re atom to complete the octahedral geometry typically found for $\mathrm{Re}=\mathrm{O}$ complexes [19].

Table 4 compares the calculated and observed vibrational modes of $\left[\mathrm{ReO}(\mathrm{Imz})(\mathrm{Hyd}) \mathrm{OH}\left(\mathrm{H}_{2} \mathrm{O}\right)_{2}\right]$. Although one must normally scale the theoretical data by optimal scaling factors, which vary by basis set, the theoretical values are usually higher than the experimental data. Figures 2, 3 show experimentally and theoretically calculated IR spectra of complex. In our case study, however, there was good agreement between the theoretical and experimental data.

In the IR, (Figure 2) the strong $v(\mathrm{Re}=\mathrm{O})$ bond of the $\left[\mathrm{ReO}(\mathrm{Imz})(\mathrm{Hyd}) \mathrm{OH}\left(\mathrm{H}_{2} \mathrm{O}\right)_{2}\right]$ complex was found in the narrow range around $910 \mathrm{~cm}^{-1}$. This value is in the lower end of the range observed for a $[\mathrm{ReO}]^{3+}$ core, and suggests that the Re-hydroxy bond competes effectively. In many investigated studies concerning the $\mathrm{M}=\mathrm{O}_{\text {oxo }}$ distances in complexes containing the $\mathrm{O}_{\text {oxo }}=\mathrm{M}-\mathrm{O}_{\text {trans }}$ fragment, they found demonstrated that when the trans 


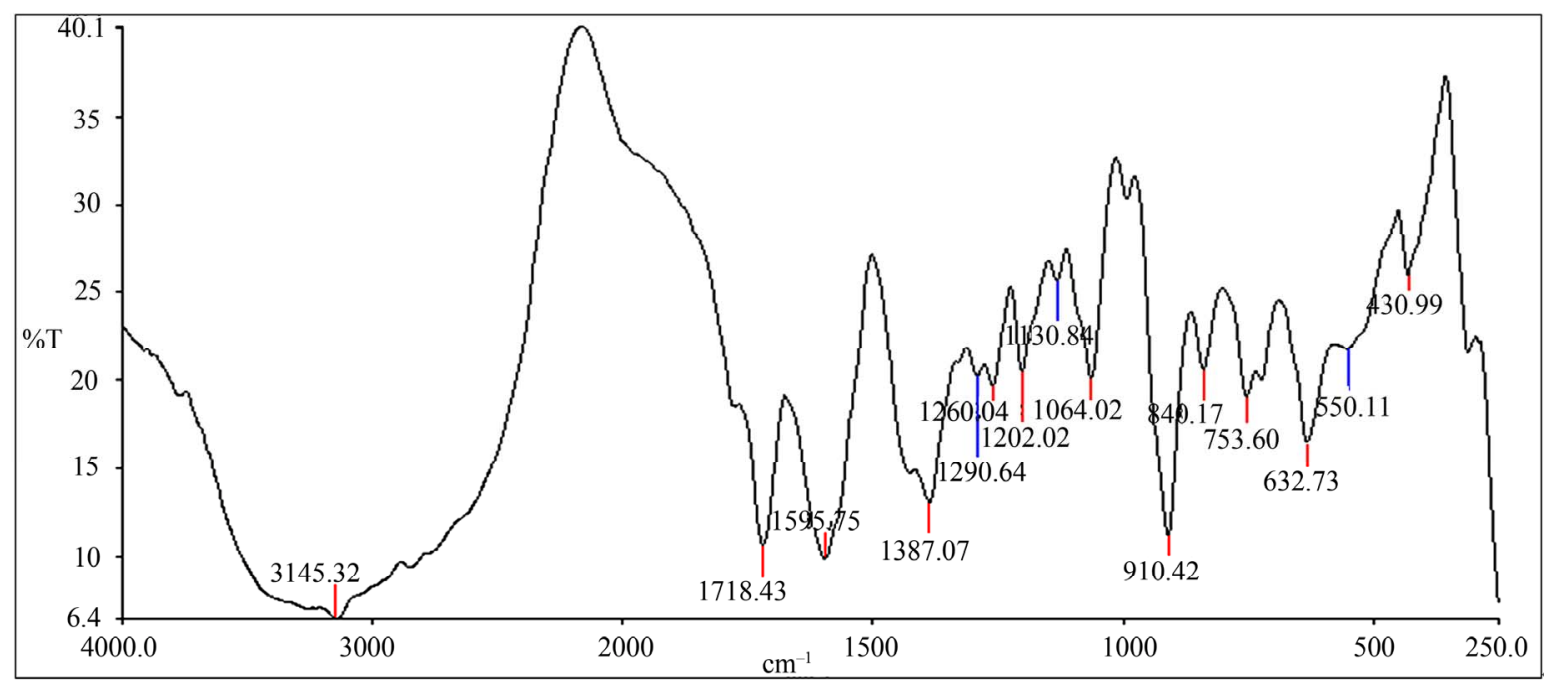

Figure 2. The IR of $\left[\mathrm{ReO}(\mathrm{Imz})(\mathrm{Hyd}) \mathrm{OH}\left(\mathrm{H}_{2} \mathrm{O}\right)_{2}\right]$.

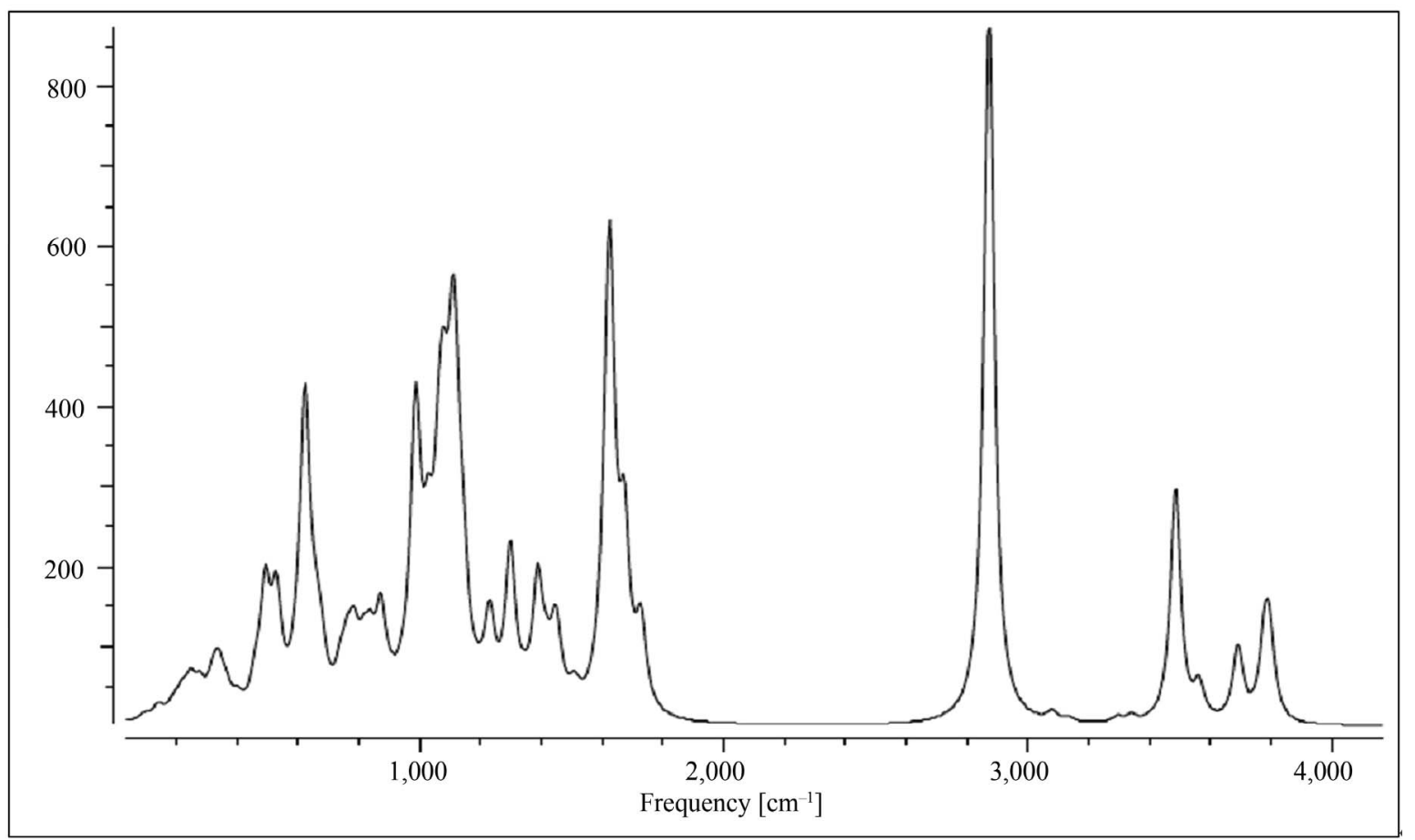

Figure 3. The Theortical IR of $\left[\mathrm{ReO}(\mathrm{Imz})(\mathrm{Hyd}) \mathrm{OH}\left(\mathrm{H}_{2} \mathrm{O}\right)_{2}\right]$.

Table 4. Comparision of the calculated and observed vibrational modes of $\left[\mathrm{ReO}(\mathrm{Imz})(\mathrm{Hyd}) \mathrm{OH}\left(\mathrm{H}_{2} \mathrm{O}\right)_{2}\right]$.

\begin{tabular}{ccc}
\hline Experimental & B3LYP/LAN2DZ & Assignment \\
\hline 560 & 694 & $v \mathrm{Re}-\mathrm{N}$ \\
632 & 730 & $v$ Re-N \\
910 & 988 & $v \mathrm{Re}=\mathrm{O}$ \\
430 & 370 & $v \mathrm{Re}-\mathrm{O}$ \\
1387 & 1460 & $v \mathrm{OH}_{\text {bend }}$ \\
3435 & 3494 & $v \mathrm{OH}_{\text {str }}$ \\
3145 & 3162 & $v \mathrm{NH}$ \\
\hline
\end{tabular}

ligand is an alcoholate $\mathrm{RO}^{-}$anion, which is a very strong Lewis base, the $\mathrm{M}=\mathrm{O}_{\text {oxo }}$ distance is long, and the $\mathrm{M}-\mathrm{O}_{\text {trans }}$ distance is very short. The short bond distance is reflected in a high value of the $v\left(\mathrm{M}=\mathrm{O}_{\text {oxo }}\right)$ stretchingmode, where $\mathrm{M}=\mathrm{Re}$, Tc [20].

In Electronic spectra (Figure 4) the experimental and calculated electronic spectra for $[\mathrm{ReO}(\mathrm{Imz})(\mathrm{Hyd}) \mathrm{OH}$ $\left.\left(\mathrm{H}_{2} \mathrm{O}\right)_{2}\right]$ complex using time-dependent density functional theory TD-DFT of the complex are presented in Table 5. The experimental absorption band at 203 and 


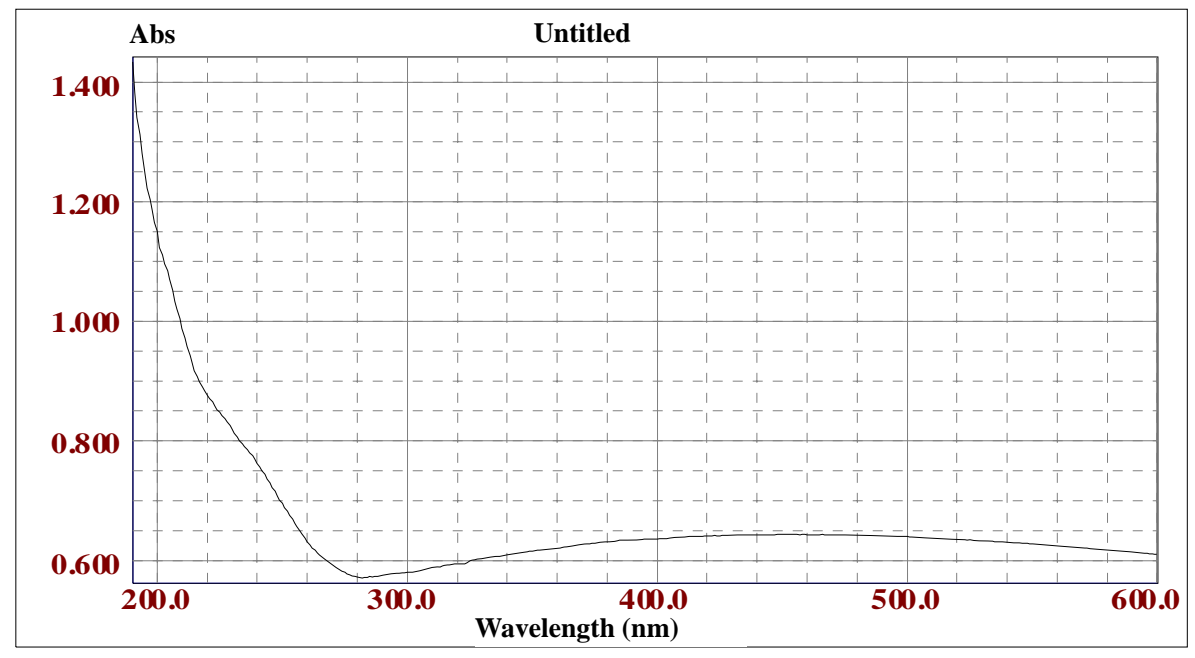

Figure 4. The UV-vis spectra of $\left[\mathrm{ReO}(\mathrm{Imz})(\mathrm{Hyd}) \mathrm{OH}\left(\mathrm{H}_{2} \mathrm{O}\right)_{2}\right]$.

Table 5. The expermentail elctronic data.

\begin{tabular}{lll}
\hline Character & $\begin{array}{l}\text { Experimental data in } \\
\text { different solvent } \lambda_{\max } \\
\mathrm{nm} .,\left(\varepsilon ; \mathrm{dm}^{3} \mathrm{~mol}^{-1} \mathrm{~cm}^{-1}\right)\end{array}$ & solvent \\
\hline$\pi \rightarrow \pi^{*}$ & $\begin{array}{l}191(2026), 203(2058), \mathrm{sh} \\
\end{array}$ & $\mathrm{H}_{2} \mathrm{O}$ \\
$\mathrm{n} \rightarrow \pi^{*}$ & $245(288)$ & \\
LMCT & $467(333), 233(333), \mathrm{sh}$ & $\mathrm{CH}_{3} \mathrm{CN}$ \\
\hline
\end{tabular}

$\varepsilon$ - molar absorption coefficient.

$191 \mathrm{~nm}$ are attributed mainly to intraligand transitions. The band recorded at $245 \mathrm{~nm}$ could be attributed to LMCT ligand metal charge transition from $\pi$-oxgyenbonding orbital to the $d$ orbital of the Re [18].

In the ${ }^{1} \mathrm{H}$ NMR spectrum of the $[\mathrm{ReO}(\operatorname{Imz})(\mathrm{Hyd})$ $\mathrm{OH}\left(\mathrm{H}_{2} \mathrm{O}\right)_{2}$ ] complex (Figure 5), the Imz ring protons appear as two doublets that are shifted markedly down field relative to the free ligands from $7 \mathrm{ppm}$ and $7.7 \mathrm{ppm}$ to $7.13 \mathrm{ppm}$ and $7.7 \mathrm{ppm}$, respectively. The NH proton signals for the Imz and $\mathrm{NH}$ ligands were absent in the spectrum of the complex and only a signal due to an $\mathrm{NH}$ of Hyd was recorded, which is shifted down field relative to the free ligand from 10 to $10.6 \mathrm{ppm}$. The ${ }^{13} \mathrm{C}$ NMR spectrum of the complex showed a signals at 174 and $158 \mathrm{ppm}$ attributed to the $(\mathrm{C}=\mathrm{O})$ bond for Hyd. In addition, the spectrum showed signals assignable to the $(\mathrm{C}=\mathrm{N})$ bond at $135 \mathrm{ppm}$ and the $(\mathrm{C}=\mathrm{C})$ at $122 \mathrm{ppm}$ for the imz ring (Figure 6).

\subsection{Quality Control of the ${ }^{99 \mathrm{~m}} \mathrm{Tc}$ Complex.}

The $\left[{ }^{99 m} \mathrm{TcO}(\mathrm{Imz})(\mathrm{Hyd}) \mathrm{OH}\left(\mathrm{H}_{2} \mathrm{O}\right)_{2}\right]$ complex can be prepared in two-steps. Quality control of the $\left[{ }^{99 m} \mathrm{TcO}(\mathrm{Imz})(\mathrm{Hyd}) \mathrm{OH}\right]$ complex was performed by thin-layer chromatography (TLC) and high-performance liquid chromatography (HPLC). The final ${ }^{99 m}$ Tc-oxo hetero complex $\left[{ }^{99 \mathrm{~m}} \mathrm{TcO}(\mathrm{Imz})(\mathrm{Hyd}) \mathrm{OH}\left(\mathrm{H}_{2} \mathrm{O}\right)_{2}\right]$ was obtained in high yield (>88\%). TLC and HPLC analyses were used to evaluate the radiochemical purity (RCP) and the stability of the complex. ITLC was performed on instant thin layer chromatography with Whatman No.1 chromatography paper and using acetone and saline as the mobile phase according to literature [16]. $R f$ values for $\left[{ }^{99 m} \mathrm{TcO}(\mathrm{Imz})(\mathrm{Hyd}) \mathrm{OH}\right]$ were around 0.6 in acetone; the other values are reported in Table 6.

The HPLC chromatograms of the $\left[{ }^{99 \mathrm{~m}} \mathrm{TcO}\right.$ (gluconate $\left.)_{2}\right]^{-}$intermediate and $\left[{ }^{99 \mathrm{~m}} \mathrm{TcO}(\mathrm{Imz})(\mathrm{Hyd}) \mathrm{OH}\left(\mathrm{H}_{2} \mathrm{O}\right)_{2}\right]$ are shown in (Figure 7). The retention time of the final ${ }^{99 \mathrm{~m}} \mathrm{Tc}$-oxo complex $\left[{ }^{99 \mathrm{~m}} \mathrm{TcO}(\mathrm{Imz})(\mathrm{Hyd}) \mathrm{OH}\left(\mathrm{H}_{2} \mathrm{O}\right)_{2}\right]$ was found to be about $9.6 \mathrm{~min}$, and that of $\left[{ }^{99 \mathrm{~m}} \mathrm{TcO}\right.$ (gluconate $\left.)_{2}\right]^{-}$intermediate was $15.6 \mathrm{~min}$. Their characterization was made using HPLC comparing their retention time $(\gamma$ detection) with the retention time of the well-defined analogous rhenium complex (UV detection at $254 \mathrm{~nm}$ ). The paper electrophoresis pattern of showed that the $\left[{ }^{99 \mathrm{~m}} \mathrm{TcO}(\mathrm{Imz})(\mathrm{Hyd}) \mathrm{OH}\left(\mathrm{H}_{2} \mathrm{O}\right)_{2}\right]$ complex moved to the point of cathode (-) percentage of radioactivity (96.20\%), suggesting that it is a cationic complex (Figure 8).

Corroboration of structure of the ${ }^{99 \mathrm{~m}} \mathrm{Tc}$-complex was achieved by comparing its HPLC profiles with the corresponding to the Re-complex. Radioactivity and U.V detectors showed identical chromatographic profiles, suggesting that the same chemical structure was formed under both synthesis conditions.

In vitro stability of the complex was evaluated by measuring the RCP in ITLC at different time points. The

Table 6. The $R f$ values of compounds in acetone.

\begin{tabular}{cccc}
\hline Compound & {$\left[{ }^{99 \mathrm{~m}} \mathrm{TcO}_{4}\right]^{-}$} & {$\left[{ }^{99 \mathrm{~m}} \mathrm{TcO}(\text { gluco })_{2}\right]$ intermediate } & {$\left[{ }^{99 \mathrm{~m}} \mathrm{TcO}-\right.$ Complex $]$} \\
\hline$R f$ & 0.9 & $0.8-1$ & 0.642 \\
\hline
\end{tabular}




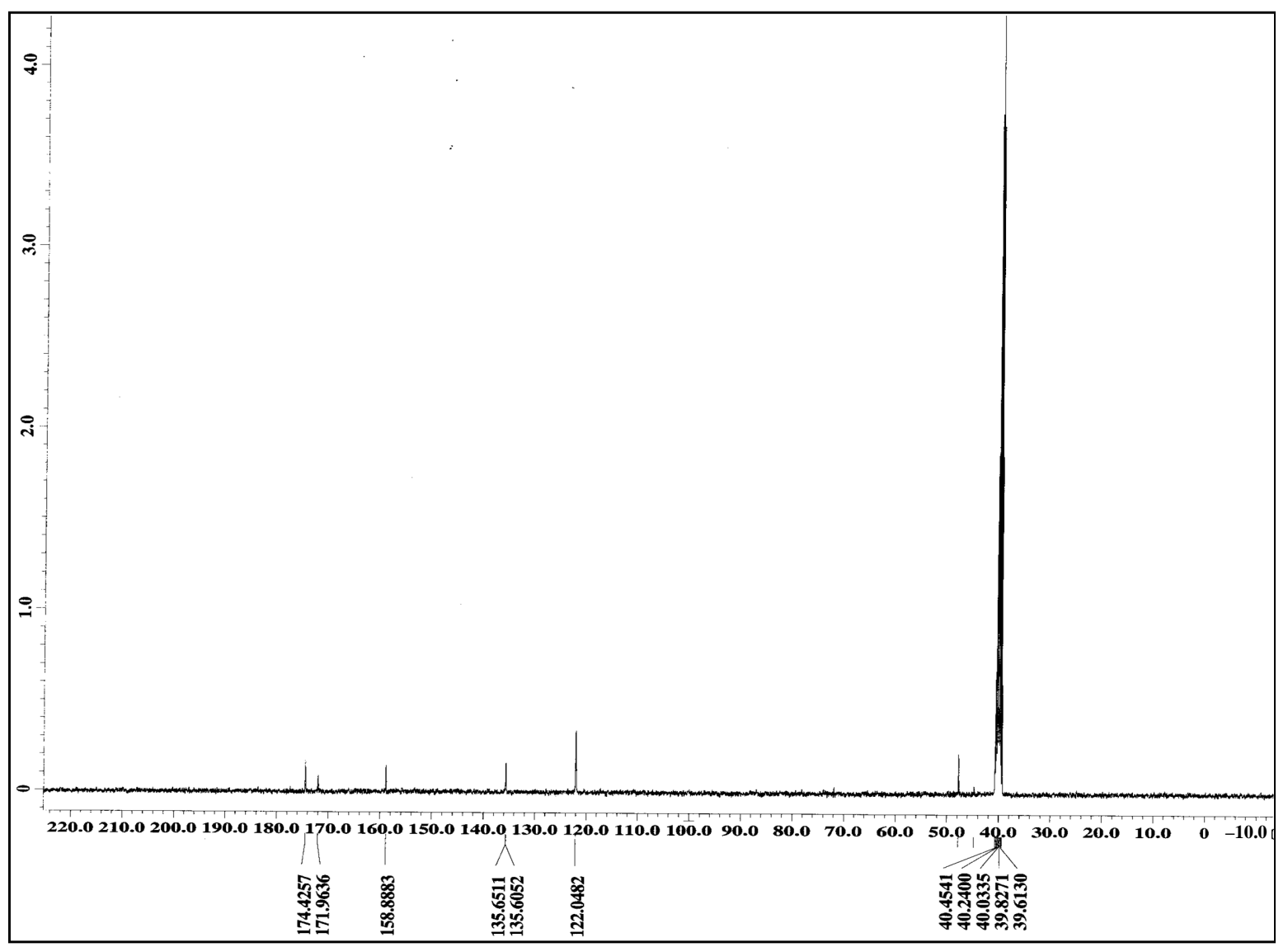

Figure 5. The ${ }^{1} \mathrm{HNMR}$ of $\left[\mathrm{ReO}(\mathrm{Imz})(\mathrm{Hyd}) \mathrm{OH}\left(\mathrm{H}_{2} \mathrm{O}\right)_{2}\right]$ complex.

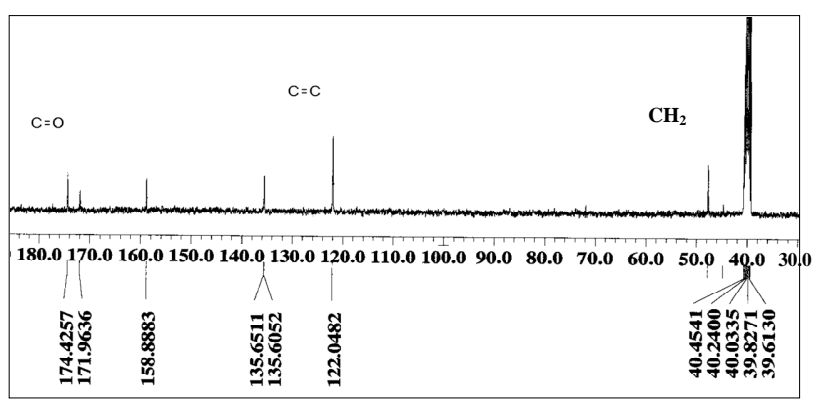

Figure 6. The ${ }^{13} \mathrm{C}$ NMR of $\left[\mathrm{ReO}(\mathrm{Imz})(\mathrm{Hyd}) \mathrm{OH}\left(\mathrm{H}_{2} \mathrm{O}\right)_{2}\right]$.

RCP was still over $96 \%$ after $5 \mathrm{~h}$, which suggested that the complex $\left[{ }^{99 \mathrm{~m}} \mathrm{TcO}(\mathrm{Imz})(\mathrm{Hyd}) \mathrm{OH}\left(\mathrm{H}_{2} \mathrm{O}\right)_{2}\right]$ possessed great stability in vitro. Stability studies of the ${ }^{99 \mathrm{~m}} \mathrm{Tc}$ complex as summarized in Table 7 , found that the complex is stable in saline and plasma for at least 5 hours, which is an important parameter to pursue with biological studies. The lipophilicity of the compound was evaluated by determination of the partition coefficient $(\mathrm{P})$ in physiological conditions (n-octanol/saline). The results obtained, were expressed as $\log \mathrm{P}_{\mathrm{O} / \mathrm{W}}$ and the data were represented as the mean \pm the standard deviation is $-0.142 \pm 0.052$. As expected, the compound has low

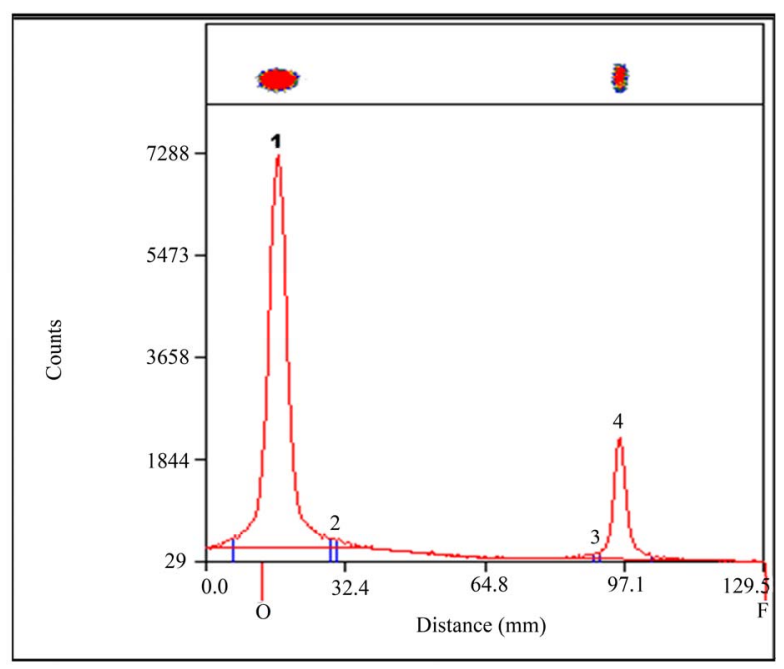

Figure 7. Chromatography ITLC of the ${ }^{99 \mathrm{~m}} \mathrm{Tc}$ labeled compound in acetone.

lipophilicity [21] (Figures 9 and 10).

The animal biodistribution experiments using $\left[{ }^{99 m} \mathrm{TcO}(\mathrm{Imz})(\mathrm{Hyd}) \mathrm{OH}\left(\mathrm{H}_{2} \mathrm{O}\right)_{2}\right]$ were performed in accordance with institutional, national and international regulations governing the safe and humane use of labo- 

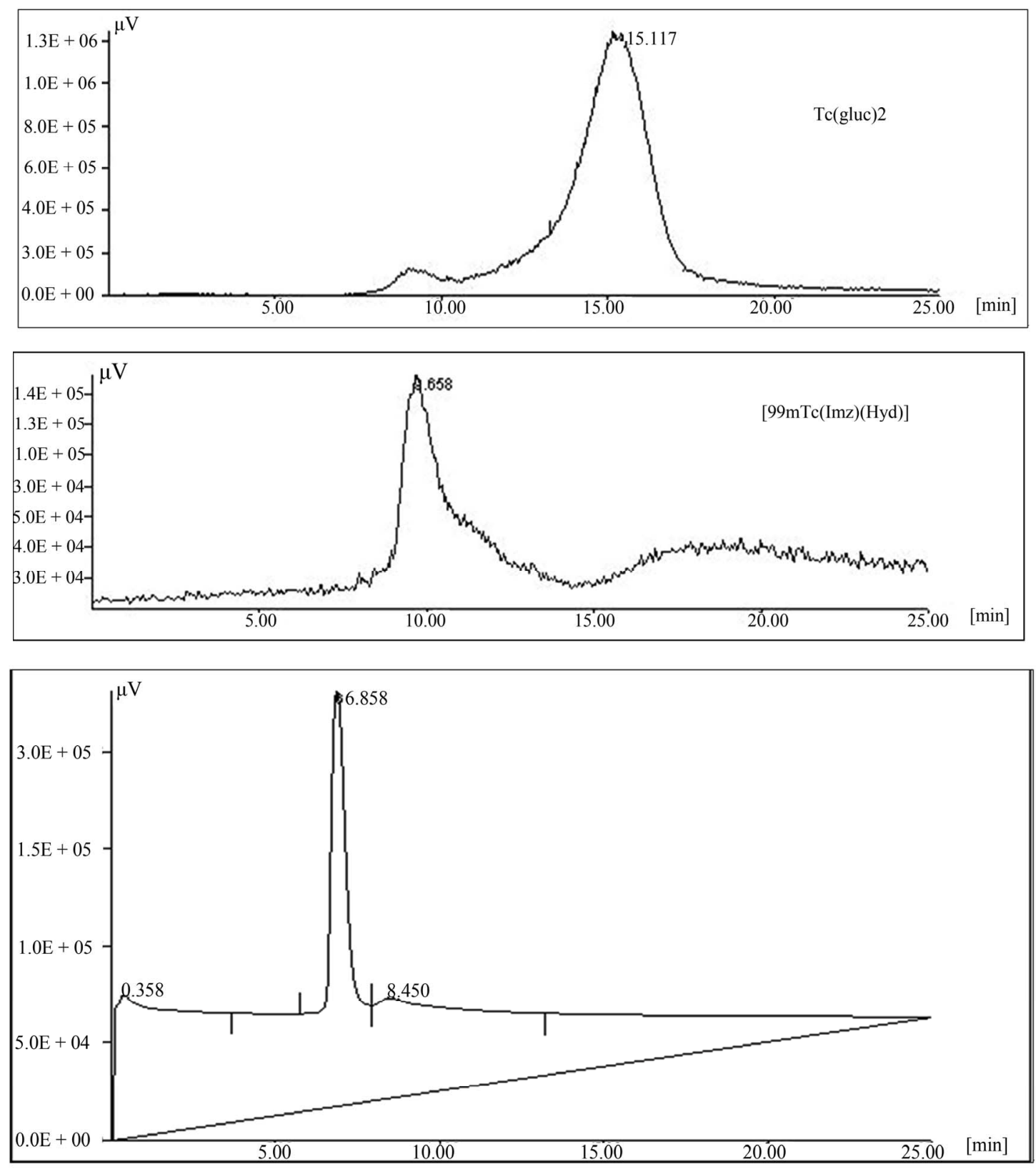

Figure 8. HPLC radio chromatogram for the $\left[{ }^{99 \mathrm{~m}} \mathrm{Tc}(\mathrm{Hyd})(\operatorname{Imz}) \mathrm{OH}\left(\mathrm{H}_{2} \mathrm{O}\right)_{2}\right]$ and $\left[\mathrm{ReO}(\operatorname{Imz})(\mathrm{Hyd}) \mathrm{OH}\left(\mathrm{H}_{2} \mathrm{O}\right)_{2}\right]$.

ratory animals in research. In Table $\mathbf{8}$, one can see theinitial heart uptake $(9.53 \pm 3.87) \% \mathrm{ID} / \mathrm{gm}$ at $5 \mathrm{~min}$ and good retention $(6.37 \pm 1.21) \% \mathrm{ID} / \mathrm{gm}$ at $60 \mathrm{~min}$. One hour after the injection, the heart/liver, heart/lung and heart/blood radioactivity ratios were $0.46,1.04$ and 0.56 , respectively. This indicates that the complex might be suitable for myocardial imaging. The radioactivity was excreted from the body via both the renal and the hepatobiliary systems. The ${ }^{99 \mathrm{~m}} \mathrm{Tc}$-complex shows moderate liver uptake and slow clearance, which may be attributable to the highly hydrophilic nature of the prepared complex. Hepatobiliary clearance of the complex is in- ferable from the gradually increasing activity in the intestinal tissue $30 \mathrm{~min}$ p.i. It was pertinent to compare the biodistribution parameters with that of $\left[{ }^{99 \mathrm{~m}} \mathrm{TcN}(\mathrm{NOEt})_{2}\right]$ [22]. The results indicate that the myocardial uptake and critical ratios of heart non-target organ (liver, lungs and blood) observed with the present compound are much lower indicating that a structural modification is required in the design of the ligand. Increasing the polar nature of the final compound could be envisaged as a possibility to reduce the lipophilicity of the complex [23]. This can be achieved by incorporating polar substituents consisting of $\mathrm{O}, \mathrm{N}, \mathrm{CO}$ donor atoms on the ligand backbone, 


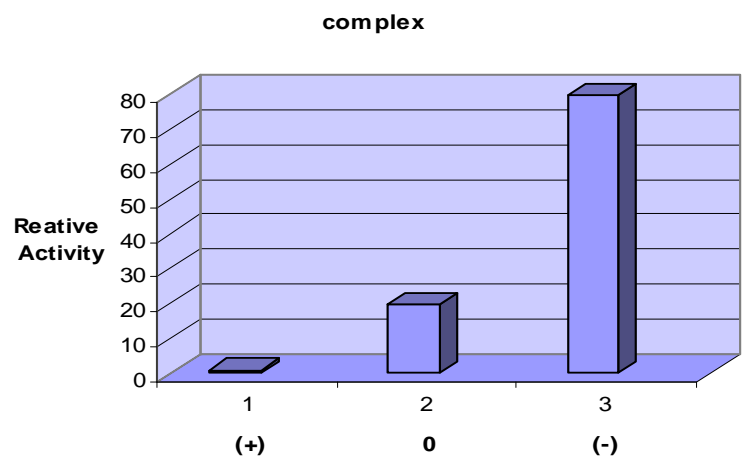

Figure 9. Electrophoresis histograms of $\left[{ }^{99 \mathrm{~m}} \mathrm{Tc}(\mathrm{Hyd})(\mathrm{Imz})\right.$ $\mathrm{OH}\left(\mathrm{H}_{2} \mathrm{O}\right)_{2}$ ]; (+)Anode; (-)Cathode; (0) neutral.

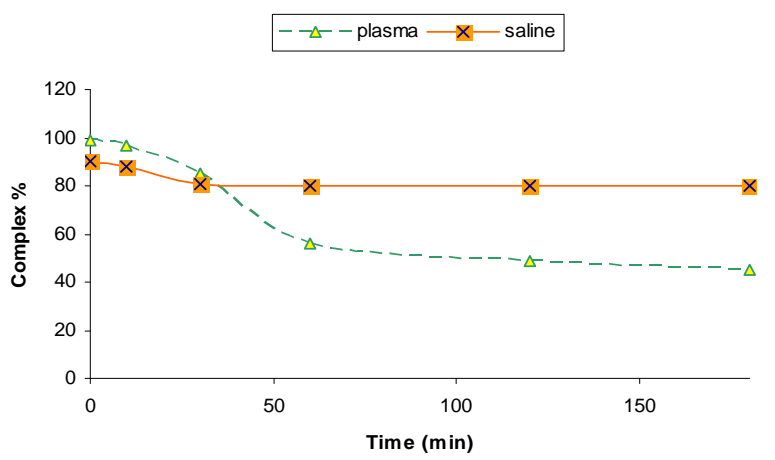

Figure 10. Stability of complex of $\left[{ }^{99 \mathrm{~m}} \mathrm{Tc}(\mathrm{Hyd})(\mathrm{Imz}) \mathrm{OH}\left(\mathrm{H}_{2} \mathrm{O}\right)_{2}\right]$ in plasma and in saline.

Table 7. The Stability of compound in Saline/Plasma.

\begin{tabular}{|c|c|c|c|c|c|c|c|c|}
\hline Compound & $\log P_{O / W}$ & Saline stab & ity $(8$ & & & asma sta & ility & \\
\hline & & $30 \mathrm{~min}$ & $1 \mathrm{~h}$ & $3 \mathrm{~h}$ & $10 \mathrm{~min}$ & $30 \mathrm{~min}$ & $1 \mathrm{~h}$ & $3 \mathrm{~h}$ \\
\hline & $0.142 \pm 0.052$ & 81 & 80 & 80 & 97 & 90 & 85 & 75 \\
\hline
\end{tabular}

Table.8. The distibution data for Complex as \% $\mathrm{ID} / \mathrm{gm}$ in mice at different time intervals.

\begin{tabular}{cccc}
\hline Organ & $5 \mathrm{~min}$ & $30 \mathrm{~min}$ & $60 \mathrm{~min}$ \\
\hline Brain & $0.59 \pm 0.25$ & $0.25 \pm 0.01$ & $0.23 \pm 0.09$ \\
Blood & $14.49 \pm 1.71$ & $8.61 \pm 1.07$ & $11.22 \pm 1.40$ \\
Liver & $16.53 \pm 4.08$ & $10.94 \pm 3.69$ & $13.63 \pm 3.27$ \\
Lung & $9.74 \pm 3.30$ & $5.66 \pm 1.65$ & $6.08 \pm 2.44$ \\
Kidney & $30.43 \pm 3.60$ & $26.0 .01 \pm 3.81$ & $31.02 \pm 6.33$ \\
Intestine & $6.22 \pm 0.69$ & $4.42 \pm 2.26$ & $8.30 \pm 1.37$ \\
Heart & $9.53 \pm 3.87$ & $7.90 \pm 0.51$ & $6.37 \pm 1.21$ \\
Muscle & $2.24 \pm 0.23$ & $2.22 \pm 2.11$ & $1.34 \pm 0.34$ \\
Spleen & $7.04 \pm 1.85$ & $1.34 \pm 0.40$ & $2.90 \pm 0.48$ \\
\hline
\end{tabular}

which in turn, will increases the clearance of the complex from the blood [5]. Additionally, it has been documented that suitable modifications such as increase in the number aliphatic substituent in the molecule enhances its clearance from liver, lungs, etc. [23] due to fast metabolism [24]. A large fraction of the activity $(35 \%)$ can be seen in the kidneys, which could possibly be due to the small size of the complex [15]. The activity appears to be retained for a long time in the kidney, diminishing a certain extent at $60 \mathrm{~min}$, perhaps owing to the metabolism of the complex within the kidney.

\section{CONCLUSIONS}

The oxorhenium complex was synthesized based on the $[\mathrm{NO}][\mathrm{N}]$, mixed ligand system and fully characterized at the macroscopic level. In this complex, a novel complex $\left[{ }^{99 \mathrm{~m}} \mathrm{TcO}(\mathrm{Imz})(\mathrm{Hyd}) \mathrm{OH}\left(\mathrm{H}_{2} \mathrm{O}\right)_{2}\right]$ was formed using (Hyd) hydantoin ligand and (Imz) imidazole ligand and the $[\mathrm{ReO}]^{+3}$ core. The chemistry was successfully transferred at the tracer level, and the corresponding oxotechnetium-99m complex was prepared using ${ }^{99 \mathrm{~m}} \mathrm{Tc}$-gluconate and by direct reduction of pertechnetate in the presence of N,N mixed ligand. Its structure was established by comparative HPLC analysis using the oxorhenium complex as a reference. Tissue distribution studies in normal mice demonstrated.

\section{ACKNOWLEDGEMENTS}

The Authors extend their appreciation to the Deanship of Scientific Research at King Saud University for funding the work through the research group project NO RGP-VPP-041.

\section{REFERENCES}

[1] Jurisson, S.S., Lever, S.Z., Lydon, J.D. and Cutler, C.S. (2004) Radioactive metal in imaging and therapy comprehensive coordination chemistry II, Subchapter 9.20.. Weily, New York, 883-911.

[2] Schwochau, K. (2000) Techenetuim chemistry and radiopharmaceutical applications. Wiley-VCH, Berlin.

[3] Papagiannopoulou, D., Pirmettis, I.C., Pelecanou, M., 
Tsoukalas, Ch., Raptopoulou, C.P., Terzis, A., Chiotellis, E. and Papadopoulos, M. (2001) Synthesis and structural characterization of a novel $\operatorname{Re}[\mathrm{P}][\mathrm{NN}][\mathrm{S}][\mathrm{SO}]$ mixed ligand rhenium (III) complex. Inorganica Chimica Acta, 320, 174-177. doi:10.1016/S0020-1693(01)00474-1

[4] Zhang, H., Dai, M., Qi, C., Li, B. and Guo, X. (2004) Synthesis, biodistribution and quantitative structure-activity relationship studies of new ${ }^{99 \mathrm{~m}} \mathrm{Tc}$ labeled pseudo-peptide complexes. Applied Radiation and Isotopes, 60, 643-651. doi:10.1016/j.apradiso.2003.08.010

[5] Dhara, B. and Chattopadhyay, P. (2005) New oxorhenium (V) complexes with $2 \mathrm{~N} 2 \mathrm{~S}$ donor sets and radiochemical behavior of their technetium analogs. Applied Radiation and Isotopes, 62, 729-735. doi:10.1016/j.apradiso.2004.10.002

[6] Shan, S., Ellern, A. and Espenson, J.H. (2002) Methyloxorhenium (V) complexes with two bidentate ligands. Inorganic Chemistry, 41, 7136-7142. doi:10.1021/ic025952f

[7] Gancheff, J., Kremer, C., Kremer, E. and Ventura, O. (2002) Density functional study of technetium and rhenium compounds. Theochem, 580, 107-116. doi:10.1016/S0166-1280(01)00601-7

[8] Machura, B., Penczek, R. and Kruszynski, R. (2007) Synthesis, crystal, molecular, and electronic structure of $\left[\mathrm{ReOCl}_{3}(\mathrm{bpzm})\right]$ complex. Polyhedron, 26, 2581-2588.

[9] Gaussian 98 program. Gaussian, Inc., Pittsburgh, PPA 15106, USA.

[10] Becke, A.D. and Pérez-Jordá, J. (1995) A density-functional study of van der Waals forces: Rare gas diatomics. Chemical Physics Letters, 233, 134-137. doi:10.1016/0009-2614(94)01402-H

[11] Parr, R.G. and Liu, S. (2000) Homogeneities in density of various LDA energy functional. Journal of Molecular Structure: THEOCHEM, 501-502, 29-34. doi:10.1016/S0166-1280(99)00410-8

[12] Hay, P.J., Chen, S.P., Voter, A.F., Albers, R.C. and Boring, A.M. (1989) Theoretical studies of grain boundaries in $\mathrm{Ni}_{3} \mathrm{Al}$ with boron or sulfur. Scripta Metall, 23, 217-222. doi:10.1016/0036-9748(89)90414-6

[13] Casida, M.E. (1996) Recent development and applications in modern density functional theory. In: Seminario, J.M., Ed., Theoretical and Computational Chemistry, 4, Elsevier, Amsterdam.

[14] Glendening, E.D., Reed, A.E., Carpenter, J.E. and Weinhold, F. (1995) NBO, Version 3.1.. University of Wisconsin, Madison.

[15] Pelecanou, M., Pirmettis, I.C., Nock, B.A., Papadopoulos, M., Chiotellis, E. and Stassinopoulou, C.I. (1998) Interaction of $[\mathrm{ReO}(\mathrm{SNS})(\mathrm{S})]$ and $\left[{ }^{99 \mathrm{~m}} \mathrm{TcO}(\mathrm{SNS})(\mathrm{S})\right]$ mixed ligand complexes with glutathione: Isolation and characterization of the product. Inorganica Chimica Acta, 281, 148-152. doi:10.1016/S0020-1693(98)00159-5

[16] Rey, A., Papadopoulos, M., Leon, E., Mallo, L., Pirmettis,
Y., Manta, E., Raptopoulou, C., Chiotellis, E. and Leon, A. (2001) Synthesis, characterization and biological evaluation of a novel " $3+1$ " mixed ligand ${ }^{99 \mathrm{~m}} \mathrm{Tc}$ complex having an aliphatic thiol as coligand. Applied $R a-$ diation and Isotopes, 54,429-434. doi:10.1016/S0969-8043(00)00285-2

[17] Bouziotis, P., Pirmettis, I., Pelecanou, M., Raptopoulou, C.P., Terzis, A., Papadopoulos, M. and Chiotellis, E. (2001) Novel oxorhenium and oxotechnetium complexes from an aminothiol[NS]/thiol[S] mixed-ligand system. Chemistry-A Europe Journal, 7, 3671-3680. doi:10.1002/1521-3765(20010903)7:17<3671::AID-CHE $\mathrm{M} 3671>3.0 . \mathrm{CO} ; 2-\mathrm{L}$

[18] Gardner, J.K., Durig, J.R., Little, T.S., Gounev, T.K. and Sullivan, F. (1996) Infrared and Raman spectra, conformational stability, vibrational assignment, and ab initio calculations of chloromethyl isocyanate. Journal of Molecular Structure, 375, 83-94.

[19] Machura, B., Kruszynski, R. and Kusz, J. (2008) Novel oxorhenium complexes with 2-(20-hydroxyphenyl)-2benzothiazolinato ligand: X-ray studies, spectroscopic characterization and DFT calculations. Polyhedron, 27, 1679-1689. doi:10.1016/j.poly.2008.02.018

[20] Machura, B., Kruszynski, R., Jaworska. M and Lodowski, P. (2005) Reactivity of $\left[\mathrm{ReOX}_{3}\left(\mathrm{PPh}_{3}\right)_{2}\right]$ complexes towards 1,4-diaminobenzene: X-ray structure and DFT calculations. Polyhydedron, 24, 1454-1460. doi:10.1016/j.poly.2005.03.094

[21] Giglio, J., Rey, A., Cerecetto, H., Pirmettis, I., Papadopoulos, M., León, E., Monge, A., López de Ceráin, A., Azqueta, A., González, M., Fernández, M., Paolino, A. and León, A. (2006) Design and evaluation of " $3+1$ " mixed ligand oxorhenium and oxotechnetium complexes bearing a nitroaromatic group with potential application in nuclear medicine oncology. European Journal of Medical Chemistry, 41, 1144-1152.

[22] Braband, H., Miroslavov, A.E., Lumpov, A.A., Sidorenko, G.V., Levitskaya, E.M., Gorshkov, N.I., Suglobov, D.N., Alberto, R., Gurzhiy, V.V., Krivovichev, S.V. and Tananaev, I.G. (2008) Complexes of technetium (I) $\left({ }^{99} \mathrm{Tc},{ }^{99 \mathrm{~m}} \mathrm{Tc}\right)$ pentacarbonyl core with $\pi$-acceptor ligands (tert-butyl isocyanide and triphenylphosphine). Journal of Organometalic Chemistry, 693, 4-10. doi:10.1016/j.ejmech.2006.05.006

[23] Tsoukalas, Ch., Pirmettis, I., Patsis, G., Papadopoulos, A., Raptopoulou,. C.P., Terzis, A., Papadopoulos, M. and Chiotellis, E. (2001) Ester-modified ${ }^{99 \mathrm{~m}} \mathrm{TcO}[\mathrm{SN}(\mathrm{R}) \mathrm{S} / \mathrm{S}]$ mixed ligand complexes: Synthesis and preliminary evaluation. Nuclear Medicine and Biology, 28, 975-982.

[24] Chattopadhyay, P., Chiu, Y.H., Lo, J.M., Chung, C.S. and Lu, T.H. (2000) Synthesis and structural characterization of a $\operatorname{Re}(\mathrm{V})$ complex with $2 \mathrm{~N} 1 \mathrm{~S}$ donor and radiochemical behavior of its Tcanalog. Applied Radiation and Isotopes, 52, 217-223. doi:10.1016/S0969-8043(99)00156-6 